\title{
SIMULATION AND OPTIMIZATION OF COUPLING REACTION OF METHANOL SYNTHESIS AND ISOPROPYL ALCOHOL DEHYDROGENATION
}

\author{
Jenny Rizkiana1, Yogi W. Budhi², Azis Trianto ${ }^{*}$ \\ ${ }^{1}$ Energy and Chemical Engineering Processing System Research Group \\ ${ }^{2}$ Chemical Engineering Process Development Research Group \\ Chemical Engineering Program, Faculty of Industrial Technology \\ Institut Teknologi Bandung \\ Jalan Ganesha No 10, Bandung 40132, Indonesia \\ Email: trianto@che.itb.ac.id
}

\begin{abstract}
A study on simulation and optimization of coupling reaction between methanol synthesis and isopropyl alcohol (IPA) dehydrogenation was performed. The analysis is carried out theoretically to obtain the optimum operation conditions which give the best performance. The reactions are just interacting thermally. In this study, both reactions are held catalytically in a heat-exchanger type reactor. As a high pressure reaction, methanol synthesis is placed in the inner side of reactor tube while dehydrogenation of IPA is in the opposite. Tube wall acts as a heat transfer media. The reactor is modeled by a steady state heterogeneous equation for a fixed bed reactor. Optimization is done in order to find the optimum value of operation conditions, those are the inlet temperature of both side of reactor and the molar feed flow ratio between the exothermic side and the endothermic side. Sum of weighted reaction conversion is considered to be the objective function that is maximized. The simulation result shows that coupled reactor makes the reaction conversion higher than a conventional adiabatic reactor and the optimum operation conditions give the maximum value of the conversion. This study presents a theoretical proof that coupling reaction is feasible.
\end{abstract}

Keywords: coupling reaction, IPA dehydrogenation, methanol synthesis, optimization, simulated annealing

\begin{abstract}
Abstrak
Telaah mengenai simulasi dan optimisasi reaksi perangkaian (coupling reaction) antara sintesis metanol dengan dehidrogenasi isopropil alkohol (IPA) telah dilakukan. Analisis dilaksanakan secara teoretik guna mendapatkan kondisi optimum yang akan memberikan hasil terbaik. Pada penelitian ini, kedua reaksi dilaksanakan secara katalitik dalam reaktor bertipe buluh-cangkang. Karena bertekanan tinggi, sintesis metanol ditempatkan pada sisi buluh, sedangkan dehidrogenasi IPA ditempatkan pada sisi cangkang. Dinding buluh berperan sebagai media perpindahan panas. Reaktor dimodelkan dengan reaktor heterogen tunak unggun tetap. Optimisasi dilakukan dalam rangka mendapatkan nilai optimum dari kondisi operasi yang mencakup temperatur inlet sisi eksotermik dan endotermik serta rasio umpan molarnya. Jumlah total konversi reaksi terbobotkan dipilih sebagai nilai objectif yang akan dioptimumkan. Hasil simulasi menunjukkan bahwa reaktor perangkaian termal mampu meningkatkan konversi reaksi jika dibandingkan dengan reaktor adiabatik dan pada kondisi operasi yang optimum diperoleh konversi maksimal. Penelitian ini menunjukkan bahwa reaksi perangkaian layak untuk dilaksanakan.
\end{abstract}

Kata kunci: reaksi perangkaian, dehidrogenasi IPA, sintesis methanol, optimisasi, simulated annealing

*corresponding author 


\section{Introduction}

Thermally coupled reactor can be considered as an effort to do energy conservation. Exothermic reaction acts as a heat source and endothermic reaction will be a heat sink. Hunter and McGuire (1978) were the first to do the study about coupling of exothermic and endothermic reaction. On their patent, they suggested to use catalytic combustion or other highly exothermic reaction as a heat source for any endothermic reaction.

Another study about reaction coupling was done by Itoh and Wu (1997). They used membrane reactor made from palladium to carry out dehydrogenation of cyclohexane. Produced hydrogen permeated trough reactor wall and reacted with oxygen giving a huge number energy to support the reactor itself, so the operation can be done adiabatically. Based on that study, Elnashaie et al. (2000) utilized heterogeneous kinetic model to simulate reaction coupling between dehydrogenation of ethyl benzene to become styrene and hydrogenation of benzene to become cyclohexane. They focused the study on the effect of co-current and countercurrent flow.

Khademi et al. (2009) chose to couple dehydrogenation of cyclohexane and methanol synthesis. They optimized the inlet temperature for both side of reaction and molar flow by using differential evolution method optimization.

This study will couple methanol synthesis and dehydrogenation of isopropyl alcohol (IPA). Methanol is a multipurpose base chemical. It is the simplest alcohol in the world and can be produced by several ways. Recently, most of methanol is made from syngas (Elkamel et al., 2009). Conventional reactor of methanol synthesis has very low conversion because of the nature of its equilibrium state. To accommodate the kinetic and equilibrium constraint, methanol synthesis should be conducted at relatively low temperature and high pressure (KirkOthmer, 1967).

IPA dehydrogenation process can be viewed from two sides. First, IPA dehydrogenation is an alternative route to make acetone. Acetone made from IPA is free from aromatic compound so that it is preferred to use by pharmaceutical industries which has very tight regulation about the solvent they used (Turton et al., 2009).
Second, IPA dehydrogenation is a way to produce hydrogen. Hydrogen is predicted to be the future fuel because of its cleanness and easy to use. Currently, most of hydrogen is produced from natural gas via steam reforming process. Due to the decrease of gas reserve in the world, alternative route to produce hydrogen must be made. Hydrogen production from IPA dehydrogenation is very potential since IPA itself can be made from renewable resources by fermentation.

Conventional optimization methods are mostly based on gradient method. From this point, at least there are two weakness of this method. First, they can easily trapped on local optimum depends on the degree of nonlinearity and initial guest (Khademi et al., 2009). Secondly, they can handle nondifferentiable objective function, such as a step function.

A number of optimization methods are developed in order to solve the weakness of conventional optimization method. One of them is called simulated annealing (SA) method. It proposed independently by Kirkpatrick et al. (1983) and Cerny (1985). This method started from implementing Metropolis algorithm combined with combinatorial optimization method and statistical mechanic to analogize and optimize annealing process. SA can be easily applied to many optimization problems (Bertsimas and Tsitsiklis, 1993).

\subsection{Kinetics Model}

Methanol synthesis actually consists of three main reactions. They are carbon oxide reduction and water-gas shift reaction as follows:

$\mathrm{CO}+2 \mathrm{H}_{2} \rightleftarrows \mathrm{CH}_{3} \mathrm{OH}$

$\mathrm{CO}_{2}+3 \mathrm{H}_{2} \rightleftarrows \mathrm{CH}_{3} \mathrm{OH}+\mathrm{H}_{2} \mathrm{O}$

$\mathrm{CO}_{2}+\mathrm{H}_{2} \rightleftarrows \mathrm{CO}+\mathrm{H}_{2} \mathrm{O}$

From those three reactions, only two are independent; the one is a combination of other ones. Van den Bussche and Froment (1996) have proposed a kinetics model based only from reaction (2) and (3) utilizing $\mathrm{Cu} / \mathrm{ZnO} / \mathrm{Al}_{2} \mathrm{O}_{3}$ as the catalyst as follows:

$$
r_{1}=\frac{k_{4} p_{\mathrm{CO}_{2}} p_{\mathrm{H}_{2}}\left(1-\frac{1}{K_{e, 1}}\left(\frac{p_{\mathrm{H}_{2} \mathrm{O}} p_{\mathrm{CH}_{3} \mathrm{OH}}}{p_{\mathrm{H}_{2}}^{3} p_{\mathrm{CO}_{2}}}\right)\right)}{\left(1+k_{3}\left(\frac{p_{\mathrm{H}_{2} \mathrm{O}}}{p_{\mathrm{H}_{2}}}\right)+k_{1} \sqrt{p_{\mathrm{H}_{2}}}+k_{2} p_{\mathrm{H}_{2} \mathrm{O}}\right)^{3}}
$$




$$
=\frac{k_{5} p_{\mathrm{CO}_{2}}\left(1-\frac{1}{K_{e, 2}}\left(\frac{p_{\mathrm{H}_{2} \mathrm{O}} p_{C O}}{p_{\mathrm{H}_{2}}^{3} p_{\mathrm{CO}_{2}}}\right)\right)}{\left(1+k_{3}\left(\frac{p_{\mathrm{H}_{2} \mathrm{O}}}{p_{\mathrm{H}_{2}}}\right)+k_{1} \sqrt{p_{\mathrm{H}_{2}}}+k_{2} p_{\mathrm{H}_{2} \mathrm{O}}\right)}
$$

Table 1. Rate Constant and Equilibrium Constant for Methanol Synthesis

\begin{tabular}{lll}
\hline $\mathbf{k}=\operatorname{Aexp}(\mathbf{B} / \mathbf{R T})$ & $\mathbf{A}$ & $\mathbf{B}$ \\
\hline $\mathrm{k}_{1}$ & 0,499 & 17197 \\
$\mathrm{k}_{2}$ & $6,62 \times 10^{-11}$ & 124119 \\
$\mathrm{k}_{3}$ & 3453,38 & - \\
$\mathrm{k}_{4}$ & 1,07 & 36696 \\
$\mathrm{k}_{5}$ & $1,22 \times 10^{10}$ & 94765 \\
\hline $\mathbf{K = 1 0}$ (A/T-B) & $\mathbf{A}$ & $\mathbf{B}$ \\
\hline $\mathrm{K}_{\mathrm{e}, 1}$ & 3066 & 10,592 \\
$\mathrm{~K}_{\mathrm{e}, 2}$ & -2703 & $-2,029$ \\
\hline
\end{tabular}

Unlike methanol synthesis, IPA dehydrogenation occurs in only one reaction. It is:

$\left(\mathrm{CH}_{3}\right)_{2} \mathrm{CHOH} \rightarrow\left(\mathrm{CH}_{3}\right)_{2} \mathrm{CO}+\mathrm{H}_{2}$

Two kinds of kinetic model are proposed by different researcher. The difference came from the difference of catalyst that is utilized. Rioux and Vannice (2005) who used Cu-Pt as a catalyst found that acetone produced from the reaction is bounded quiet strongly on the surface of catalyst. Han et al.(2000) found the opposite phenomena because they used $\mathrm{Cu} / \mathrm{SiO}_{2}$ as catalyst. In this study, kinetics model that will be used is the model proposed by Rioux and Vannice (2005) as follow:

$r_{A c e}=\frac{k K_{I P A} P_{I P A}}{\left(1+K_{I P A} P_{I P A}+\left(K_{H_{2}} P_{H_{2}}\right)^{\frac{1}{2}}+K_{A C E} P_{A C E}\right)^{2}}$

Table 2 Rate Constant and Equilibrium Constant for IPA Dehydrogenation

\begin{tabular}{ccr}
\hline $\mathbf{k}=\mathbf{A e x p}(\mathbf{B} / \mathbf{R T})$ & $\mathbf{A}$ & \multicolumn{1}{c}{$\mathbf{B}$} \\
\hline $\mathrm{k}$ & 1,422 & $-5319,52$ \\
\hline $\mathbf{K = 1 0}$ (A/T-B) & $\mathbf{A}$ & $\mathbf{B}$ \\
\hline $\mathrm{K}_{\mathrm{IPA}}$ & 2889,711 & 3,775 \\
$\mathrm{~K}_{\mathrm{H} 2}$ & 7200,097 & 19,154 \\
$\mathrm{~K}_{\mathrm{ACE}}$ & 3166,866 & 6,180
\end{tabular}

\subsection{Reactor Mathematical Model}

One dimensional heterogeneous reactor model is generated to determine concentration and temperature profile along the reactor. There are several assumptions that are used to develop the model. They are:

- Steady state operation for both sides of reactor;

- Radial concentration and temperature profile are neglected;

- Axial diffusion is negligible;

- Bed porosity is constant in all part of reactor;

- Chemical reaction only occurs at catalyst surface;

- Heat loss to surrounding is neglected; and

- Co-current flow operation.

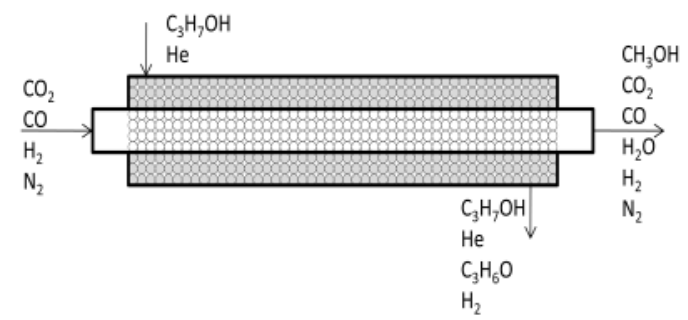

Figure 1. Shell-and-tube catalytic reactor; methanol synthesis is done in tube side while IPA dehydrogenation is in shell side

Based on those assumptions, mathematical model for the reactor can be generated and divided into two phase, those are solid phase and fluid phase. Figure 1 shows the schematic image of shell-and-tube catalytic reactor. Methanol synthesis is done in the tube side while IPA dehydrogenation is in the other side. For solid phase, mass and energy balances is expressed by:

$\frac{a_{v} k_{g i, j}}{A_{c} u_{g}}\left(n_{i, j}^{g}-n_{i, j}^{s}\right)+r_{i, j} \rho_{b}=0$

$a_{v} h_{f}\left(T_{j}^{g}-T_{j}^{s}\right)+\rho_{b} \sum_{i=1}^{N} r_{i, j}\left(-\Delta H_{f, i}\right)=0$

Mass and energy profile is occurred in fluid phase. The equation for mass and energy balances for this phase are written on Table 3.

\section{Optimization problem}

Experimental factor that will be manipulated and optimized are inlet temperature of exothermic side (T1), inlet temperature of endothermic side (T2), and molar feed flow ratio (R12). T1 will be varied between $200-260{ }^{\circ} \mathrm{C}$ while $\mathrm{T} 2$ will be varied at $150-250{ }^{\circ} \mathrm{C}$. R12 is unbounded since it has no theoretical restriction. 
Table 3. Auxiliary Correlation for Estimating Fluid Properties and Transport Coefficient

\begin{tabular}{|c|c|c|}
\hline Parameter & Correlation & Reference \\
\hline $\begin{array}{l}\text { Heat capacity for pure } \\
\text { component } \\
\text { Mix heat cap. } \\
\text { Viscosity } \\
\text { Mix viscosity } \\
\text { Thermal cond. } \\
\text { Mix thermal cond. }\end{array}$ & $\begin{array}{l}C_{p}=A+B\left(\frac{C}{T} / \sinh \left(\frac{C}{T}\right)\right)^{2}+D\left(\frac{E}{T} / \cosh \left(\frac{E}{T}\right)\right)^{2} \\
\text { Based on local composition } \\
\text { Chung correlation } \\
\text { Wilke correlation } \\
\text { Chung correlation } \\
\text { Korelasi Brokaw }\end{array}$ & $\begin{array}{l}\text { Reid et al., } 1987 \\
\text { Reid et al., } 1987 \\
\text { Reid et al., } 1987 \\
\text { Reid and Sherwood, } 1958\end{array}$ \\
\hline $\begin{array}{l}\text { Mass transfer } \\
\text { coefficient }\end{array}$ & $\begin{array}{c}k_{g i}=1.17 R e^{-0.42} S c_{i}^{-0.67} u_{g} \times 10^{3} \\
R e=\frac{2 R_{p} u_{g}}{\mu} \\
S c_{i}=\frac{\mu}{\rho D_{i m} \times 10^{-4}} \\
D_{i m}=\frac{1-y_{i}}{\sum_{i=j} \frac{y_{i}}{D_{i j}}} \\
D_{i, j}=\frac{10^{-7} T^{3 / 2} \sqrt{\frac{1}{M_{i}}+\frac{1}{M_{j}}}}{P\left(v_{c i}^{3 / 2}+v_{c j}^{2 / 3}\right)^{2}}\end{array}$ & Cussler, 2009 \\
\hline $\begin{array}{l}\text { Heat transfer } \\
\text { coefficient }\end{array}$ & $\begin{aligned} \frac{1}{U} & =\frac{1}{h_{i}}+\frac{A_{i} \ln \frac{D_{o}}{D_{i}}}{2 \pi K_{w} L}+\frac{A_{i}}{A_{o}} \frac{1}{h_{o}} \\
\left(\frac{h d_{p}}{\lambda}\right) & =1.17\left(\frac{\rho u d_{p}}{\mu}\right)^{0.585}\left(\frac{C_{p} \mu}{\lambda}\right)^{1 / 3}\end{aligned}$ & McCabe et al., 1993 \\
\hline
\end{tabular}

Sum of weighted reaction conversion is considered to be the objective function. Weighted factor for this study is the price of each component. But, since price study hasn't finished yet, we assumed that weighted factors are equals for all components. Therefore, the objective function is just sum of reaction conversion multiplied by $(-1)$ because most of optimization method require an objective function to be minimized.

We classify this optimization problem as a constrained problem. To make it as an unconstrained one, a penalty function can be added to the objective function. Penalty function is function for penalizing the objective function when the variable violates its constraint. For example, if variable satisfy the constraint, penalty function is zero; otherwise, penalty function will be a finite value. For this study, the penalty values are:

$P F=\beta \sum_{i=1}^{n} G_{i}^{2}$

Where

$G_{1}=\max \left\{0,\left(T_{2}-T_{1}\right)\right\}$

$G_{2}=\max \left\{0,\left(150-T_{02}\right)\right\}$

$G_{1}=\max \left\{0,\left(T_{02}-250\right)\right\}$

$G_{1}=\max \left\{0,\left(200-T_{01}\right)\right\}$

$G_{1}=\max \left\{0,\left(T_{01}-260\right)\right\}$

\section{Result and Discussion}

For a base case, all conditions of methanol synthesis Van den Bussche and Froment (1996) are used, excluding feed composition since it is used from SinadinovicFiser et al. (2001). For IPA dehydrogenation, reaction condition is taken from Rioux and Vannice (2005).

Before the thermally coupled reactor is simulated, first we have to simulate the conventional adiabatic reactor. Figure 2 shows the effect of inlet temperature to the yield of methanol. We can see that when temperature increases, yield of methanol is also increase. But at some point, methanol yield will remain constant and then decrease. This is because at low temperature, methanol synthesis is controlled by kinetics. However, as temperature increases, the reaction changes to be thermodynamically controlled.

The effect of temperature to acetone yield can be seen on figure 3. Since IPA dehydrogenation is an endothermic reaction and it is kinetically controlled, temperature increase gives positive effect to the yield. The higher temperature will make acetone yield higher. 


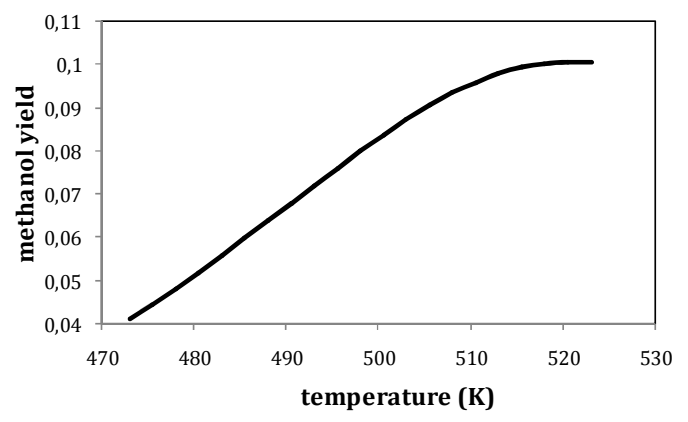

Figure 2. Inlet temperature vs methanol yield

As described before, optimization is done in order to get the best conditions which give the maximum conversion for both side of reactor. Optimization process was carried out using Simulated Annealing method. The results are summarized in Table 4 . All value from optimization results is then used to simulate the optimized coupled reactor.

Table 4. Optimized Condition for Thermally Coupled Reactor

\begin{tabular}{lr}
\hline Parameter & \multicolumn{1}{c}{ Value } \\
\hline Inlet temperature of & \\
exothermic side (K) & 525.82 \\
Inlet temperature of & \\
endothermic side (K) & 512.46 \\
Molar feed flow ratio & 0.195 \\
\hline
\end{tabular}

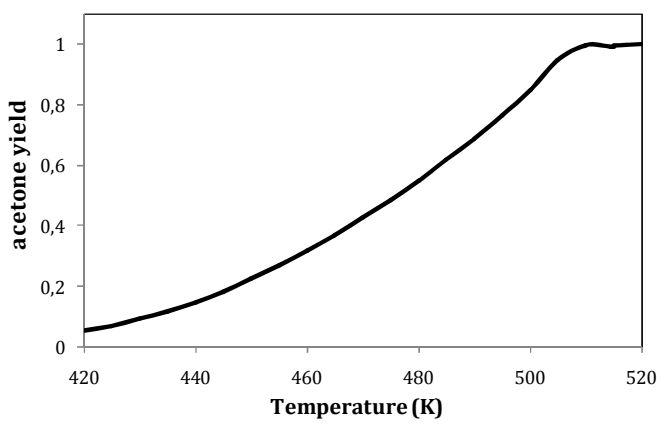

Figure 3. Inlet temperatures vs. acetone yield

Reactor simulation results carried out by using optimized conditions are shown in several figures. Figure 4 shows temperature and yield profile for both side of reactor. From figure 4(a), we can see that temperature of exothermic side is relatively remains constant. It means that all heat generated from reaction of methanol synthesis is absorbed and being used by IPA dehydrogenation to maintain its process.
As a highly endothermic reaction, IPA dehydrogenation needs much energy. Energy can come from additional heat sources or from the system itself. If heat from additional sources isn't enough, reaction will use its internal energy. It is marked by the decrease of reactor temperature as shown on figure 4 (a) at earlier section of reactor (between 0 until 0.1). When reaction occurs, it needs a huge number of energy, but when conversion almost reaches $100 \%$ (reaction rate almost zero), it doesn't needs energy anymore (see figure 4(b)). So, the energy from methanol synthesis is used to regain temperature.

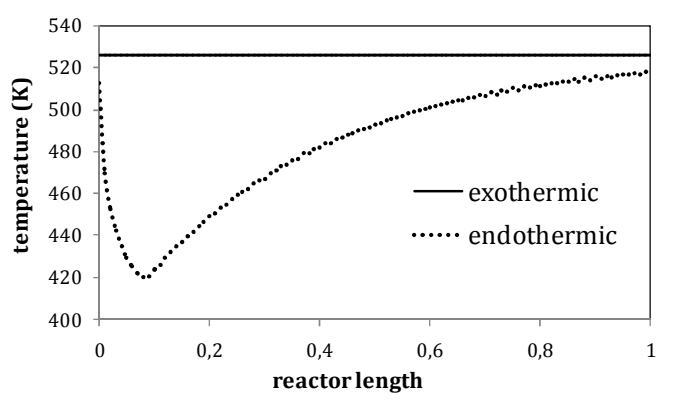

(a)

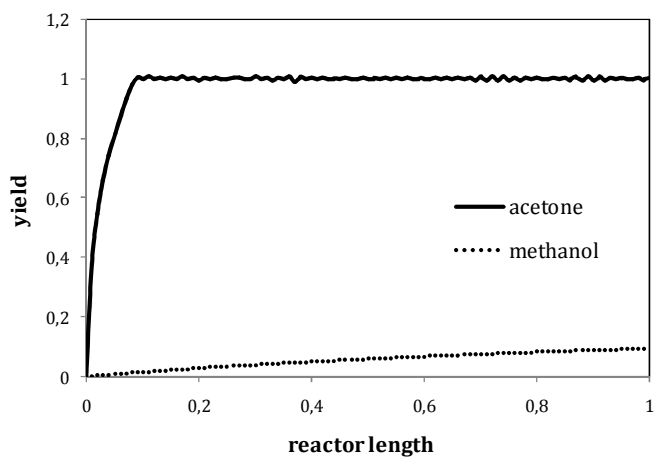

(b)

Figure 4. Yield and temperature profile at optimized condition; (a) temperature profile, (b) yield profile

Figure 5 shows comparison between endothermic side temperatures of optimized coupled reactor (OCR) with temperature of conventional adiabatic reactor (CAR) at the same inlet condition. From that figure, it is shown that by using OCR, maximum acetone yield can be achieved quicker than by using CAR. On the OCR, maximum acetone yield achieved at about 0.1 lengths of reactor and on the CAR at about 0.8 (see figure 6). It's because on OCR, IPA dehydrogenation gets additional energy from methanol synthesis. It is cleared that OCR gives better performance than CAR. 


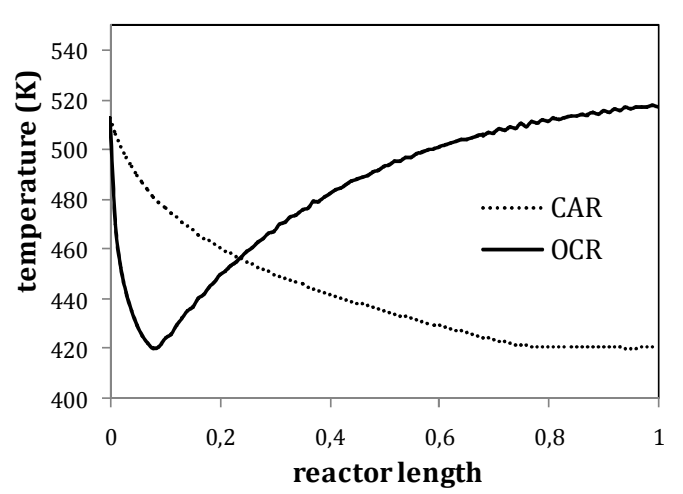

Figure 5. Comparison of temperature profile of IPA dehydrogenation between conventional adiabatic reactor (CAR) and optimized coupled reactor (OCR)

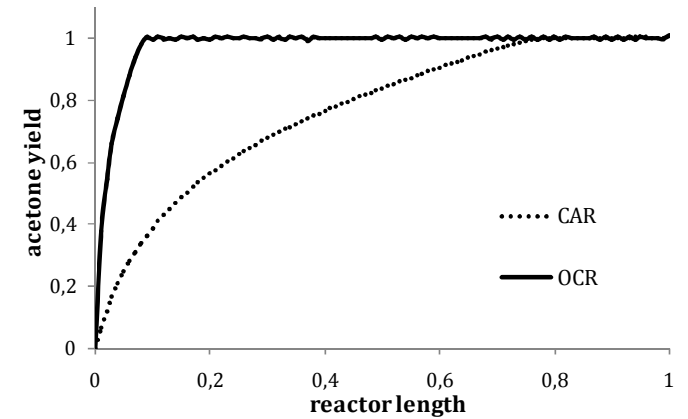

Figure 6. Mole fraction profile along the reactor for endothermic side

\section{Conclusion}

The simulation and optimization of thermally coupled reactor was studied. As an indirect coupling reaction, the reactor consists of two separated sides. They are exothermic side and endothermic side. Optimization process is performed by applying simulated annealing algorithm. It is shown that energy generated by methanol synthesis reaction is enough to maintain the reaction itself and also to make IPA dehydrogenation occurred faster and better. Compare to conventional adiabatic reactor, optimized coupled reactor has some advantages, such as auto-thermal can be achieved and product temperature of exothermic reaction is lower so that higher conversion is reached.

\section{Notations}

$a_{\mathrm{v}}=$ Specific area of catalyst $\left(\mathrm{m}^{2} / \mathrm{m}^{3}\right)$

$A_{c}=$ Cross section area $\left(\mathrm{m}^{2}\right)$

$A_{i}=$ Inside Area of tube $\left(\mathrm{m}^{2}\right)$

$A_{0}=$ Outside area of tube $\left(\mathrm{m}^{2}\right)$

$\mathrm{C}_{\mathrm{p}}=$ Heat capacity of gases $(\mathrm{J} / \mathrm{mol} . \mathrm{K})$

$\mathrm{d}_{\mathrm{p}}=$ Particle diameter $(\mathrm{m})$

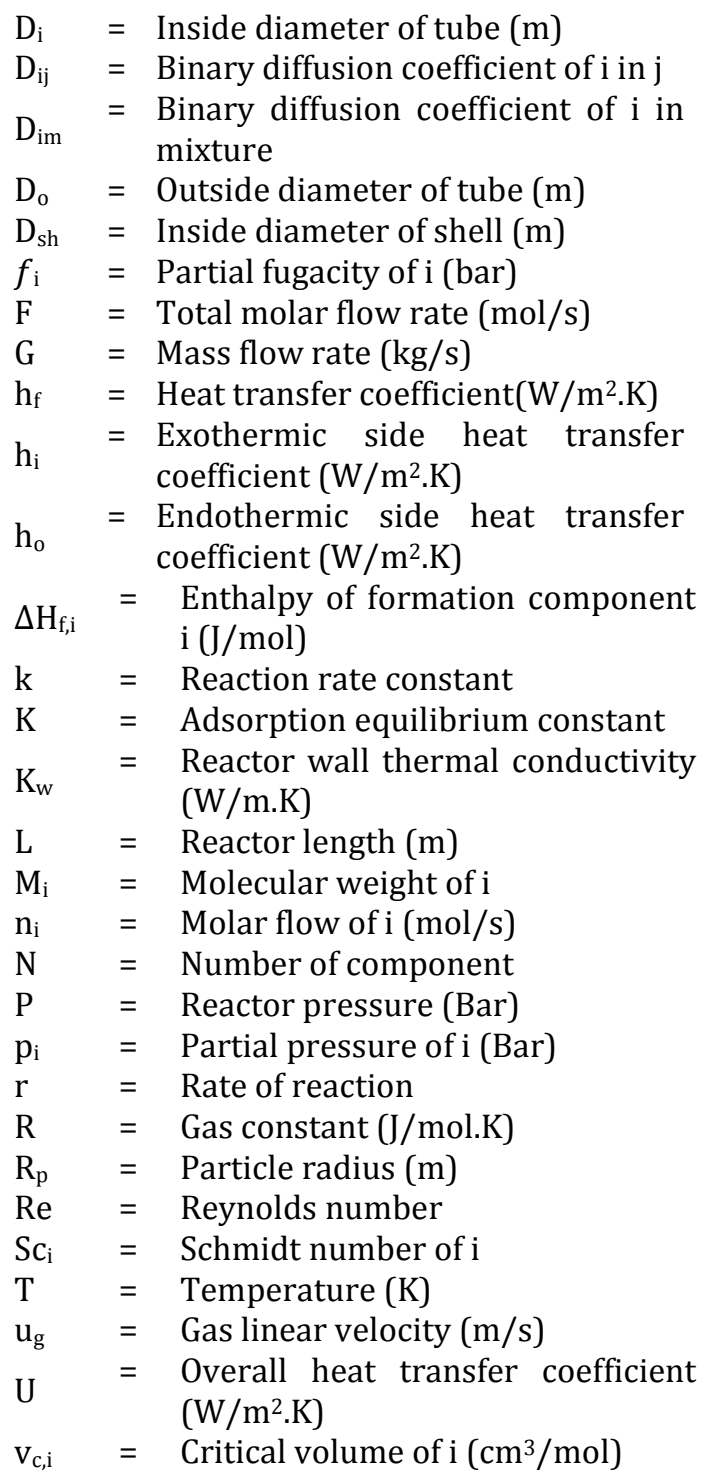

\section{References}

Bertsimas, D.; Tsitsiklis, J., Simulated annealing, Statistical Science, 1993, 8(1), 1015.

Bussche, K. M. V.; Froment, G. F., A steadystate kinetic model for methanol synthesis and the water gas shift reaction on a commercial $\mathrm{Cu} / \mathrm{ZnO} / \mathrm{Al}_{2} \mathrm{O}_{3}$ catalyst, Journal of Catalysis, 1996, 161(1), 1-10.

Cerny, V., Thermodynamical approach to the traveling salesman problem: An efficient simulation algorithm, Journal of Optimization Theory and Application, 1985, 45(1), 41-51.

Cussler, E. L., Diffusion: Mass Transfer in Fluid System; Cambridge University Press: Cambridge, 2009. 
Elkamel, A.; Zahedi, G. R.; Marton, C.; Lohi, A., Optimal fixed bed reactor network configuration for the efficient recycling of co2 into methanol, Energies, 2009, 2(2), 180-189.

Elnashaie, S. S. E. H.; Moustafa, T.; Alsoudani, T.; Elshishini, S. S., Modeling and basic characteristics of novel integrated dehydrogenation-hydrogenation membrane catalytic reactors, Computers \& Chemical Engineering, 2000, 24(2-7), 1293-1300.

Han, Y.; Shen, J.; Chen, Y., Microkinetic analysis of isopropanol dehydrogenation over $\mathrm{Cu} / \mathrm{SiO}_{2}$ catalyst, Applied Catalysis A: General, 2001, 205(1-2), 79-84.

Hunter, J. B.; McGuire, G., Method and Apparatus for Catalytic Heat Exchange, US Patent 925,862, 18 Juli 1978.

Itoh, N.; Wu, T., An adiabatic type of palladium membrane reactor for coupling endothermic and exothermic reactions, Journal of Membrane Science, 1997, 124(2), 213-222.

Khademi, M. H.; Setoodeh, P.; Rahimpour, M. R.; Jahanmiri, A., Optimization of methanol synthesis and cyclohexane dehydrogenation in a thermally coupled reactor using differential evolution (DE) method, International Journal of Hydrogen Energy, 2009, 34(16), 6930-6944.

Kirk-Othmer, Encyclopedia of Chemical Technology; John Wiley \& Sons: New York, 1967.
Kirkpatrick, S.; Gelatt, C. D.; Vecchi, M. P., Optimization by simulated annealing, Science, 1983, 220(4598), 671-680.

McCabe, W. L.; Smith, J. C.; Hariott, P., Unit Operation of Chemical Engineering; McGrawHill: New York, 1993.

Sinadinovic-Fiser, S. V.; Jankovic, M. R.; Radicevic, R. Z., Simulation of the fixed bed reactor for methanol synthesis, Petroleum and Coal, 2001, 43(1), 31-34.

Green, D. W.; Perry, R. H., Perry's Chemical Engineers' Handbook; McGraw-Hill: New York, 2007.

Reid, R. C.; Prausnitz, J. M.; Poling, B. E., The Properties of Gases and Liquids; McGraw-Hill: New York, 1987.

Reid, R. C.; Sherwood, T. K., The Properties of Gases and Liquids: Their Estimation and Correlation; McGraw-Hill: New York, 1958.

Rioux, R. M.; Vannice, M. A., Dehydrogenation of isopropyl alcohol on carbon-supported $\mathrm{Pt}$ and $\mathrm{Cu}-\mathrm{Pt}$ catalysts, Journal of Catalysis, 2005, 233(1), 147-165.

Turton, R.; Bailie, R. C.; Whiting, W. B.; Shaeiwitz, J. A., Analysis, Synthesis, and Design of Chemical Processes; Prentice-Hall: New Jersey, 2009. 